\title{
Grape Root Borer: A Review of the Life Cycle and Strategies for Integrated Control
}

\author{
William C. Olien ${ }^{1}$ \\ Department of Horticulture, Clemson University, Clemson, SC 29634-0375 \\ Barbara J. Smith \\ U.S. Department of Agriculture, Agricultural Research Service, Small Fruit Research Station, Box 287, \\ Poplarville, MS 39470 \\ C. Patrick Hegwood, Jr. \\ Mississippi State University, Truck Crops Branch Experiment Station, Box 231, Crystal Springs, MS 39059
}

Grape root borer (Vitacea polistiformis Harris) (GRB) is native to the eastern United States, roughly south of a line from Vermont to Minnesota, and has long been an important pest of grapes (All et al., 1987; Clark and Enns, 1964; Dutcher and All, 1976; McGiffen and Neunzig, 1985; Pellet, 1975). The species name is indicative of this clear-winged moth's resemblance to Polistes spp. wasps in coloration, body shape, and flight habit (Brooks, 1907). However, the moth does not have the wasp's distinctive narrow abdomen. GRB's host range is restricted to Vitis spp. Vineyard infestations commonly originate from GRB populations in wild grapes that grow abundantly in the GRB distribution (All et al., 1987) region. Some states have reported severe reductions in grape yields, and some vineyards have been completely replanted (Dutcher and All, 1976; McGiffen and Neunzig, 1985; Pellet, 1975). Other areas have ceased grape production because of this vest (Pollet,1975). Early reports stated that muscadine grapes (Vitis rotundifolia Michx.) were immune to GRB, but these were later found to be erroneous (Wylie and Johnson, 1978).

GRB has been a difficult pest to detect and control because it spends most of its life cycle underground, feeding on grape roots and the trunk crown (All and Dutcher, 1977; Clark and Enns, 1964). Vineyards are usually infested over several seasons (Dutcher and All, 1976). Symptoms of vine decline may not be evident for several seasons after initial infestation (Dutcher and All, 1976; Pellet, 1975), or the vine may be killed by a single GRB if the trunk is girdled at the base (Dutcher and All, 1979). Dutcher and All (1979) estimated that a single GRB larvae consuming $21 \%$ of the outer circumference of the trunk base would decrease shoot growth and fruit yield by $90 \%$. At least 42 larval feeding sites over the root system can also kill the vine without crown girdling. An economic threshold for GRB control was estimated to be 73 larvae/ha. Thus, control practices should be part of normal vineyard man-

\footnotetext{
Received for publication 11 Dec. 1992. Accepted for publication 14 June 1993. Technical Contribution no. 3369 of the South Carolina Agricultural Experiment Station, Clemson Univ. The cost of publishing this paper was defrayed in part by the paymentof page charges. Under postal regulations, this paper therefore must be hereby marked advertisement solely to indicate this fact.

'To whom reprint requests should be addressed.
}

agement and should not be delayed until the presence of GRB is detected.

\section{LIFE CYCLE AND VINE INJURY}

Brooks (1907), Clark and Enns ( 1964), and Sarai (1972) described essential aspects of the GRB life cycle, including mortality estimates at each stage, response to environmental conditions, and suspected pathogens and predators of GRB.

The GRB reproductive process begins as female moths emit a pheromone complex to attract males (Schwarz et al., 1983; Snow et al., 1987). After mating, the female oviposits from 200 to 500 eggs over an average of 8 days, depositing them singly on soil, weeds, and grape foliage (Dutcher and All, 1978a). Dutcher and All (1978b) estimated that $\approx 50 \%$ of the eggs are laid in the first day. The female is initially sluggish in flight due to the weight of the egg mass; therefore, she deposits most of the eggs near the vine trunk. As egg deposition continues, she can fly more efficiently and distribute the remaining eggs at considerable distances from where she emerged and mated (Clark and Enns, 1964).

Eggs hatch in $\approx 20$ days, and first-instar larvae immediately burrow into the soil in search of grape roots. Newly hatched larvae must find grape roots to survive, but they show no preference for any vine age or root size. GRB larvae may pass through six instars (McGiffen and Neunzig, 1985) and remain in the soil, feeding on grape roots, for 1 to 3 years (average of 22 months) (Clark and Enns, 1964; Sarai, 1972). The larvae begin feeding on the inner bark and consume all tissues within the outer bark as they grow. Such injury may entirely girdle and kill the root or trunk base. In large roots, larvae may bore tunnels that extend as far as $1 \mathrm{~m}$ (Dutcher and All, 1976) and increase in diameter as larvae grow and progress toward the trunk. If larval feeding kills a large root, other larvae feeding on roots distal to the site of injury will likely die of starvation (Clark and Enns, 1964). However, larvae are capable of migrating short distances through the soil in search of new grape roots (Sarai, 1972). Initially, larvae are distributed uniformly over the root system, but migration of the larvae within and between roots tends to concentrate the later instar larvae near the trunk base (Clark and Enns, 1964; Dutcher and All, 1978b; Sarai, 1972). To begin pupation, the last instar larvae spin a cocoon $\approx 3$ to $4 \mathrm{~cm}$ long near the soil surface. pupae are distributed evenly around the trunk, decreasing exponentially with increasing radius from the trunk (Dutcher and All, 1978b). About 50\%. are found within $12 \mathrm{~cm}$ and $90 \%$ within $35 \mathrm{~cm}$ of the trunk, but some pupae are found as far as $1 \mathrm{~m}$ from the trunk. Pupation occurs over 30 to 45 days from early June to mid July. At the end of this period, pupae emerge half way out of the cocoon, with their anterior end extending above the soil. The pupal skin then splits and the adults emerge. The combined cocoon and pupal cast near the trunk is evidence of GRB infestation in a vineyard.

Adult moths emerge from the soil between early summer and early fall. This period is shorter in dry, warm years and longer in wet, cool years (Clark and Enns, 1964). Emergence takes longer in wet, cool years because adults tend to emerge during drier periods. Emergence duration also increases from the northern to the southern end of GRB distribution, ranging from 2 months in New Jersey, Maryland, and Pennsylvania to 6 months in Florida (Snow et al., 1991). The period of adult emergence is distributed around a single peak in northern GRB regions, but two peaks generally occurred toward the southern end of the GRB range.

Dutcher and All (1978d) developed a model, based on degree days (10C base temperature) and sugar accumulation in 'Concord' grape berries, to predict time of adult emergence in Georgia. However, Snow et al. (1991) found that adult GRB moths emerged later in the year as one moved south from Pennsylvania to Florida. Webb et al. (1992) concluded that Dutcher and All's model was correlative for conditions in Georgia, but it did not predict time of emergence in other regions. Webb et rd. (1992) suggested that GRB emergence was more likely related to soil temperature, moisture, and $\mathrm{O}_{2}$ level and to active periods of grape root growth, rather than growing degree days or berry sugar level. A mechanistic model of environmental effects on adult GRB emergence might be developed based on these factors.

\section{DETECTING GRB INFESTATION}

The four primary methods of detecting GRB infestations in vineyards (All et al.,1987; Dutcher and All, 1979; Schwarz et al., 1983; 
Snow et al., 1987) are 1) looking for symptoms of vine decline; 2) counting pupal cases within $60 \mathrm{~cm}$ of the trunk of vines that appear to be in decline; 3 ) excavating a portion of the root system and counting larvae, feeding sites, and percentage of trunk girdling; and 4) using pheromone traps to count adult males present in vineyards. Detection can be difficult even with severe infestations, because, in vineyards heavily damaged by GRB for several years, GRB populations usually decline as their food source decreases (Wylie and Johnson, 1978). Vine symptoms of GRB damage include reduced shoot growth, smaller leaves, fewer bunches, and smaller berries. Vines usually begin to show symptoms when 5 to 10 years old and progressively decline over 3 to 5 years (All et al., 1987).

\section{OPPORTUNITIES AND STRATEGIES FOR GRB CONTROL}

Eggs and first-instar larvae are the most vulnerable stages in the GRB life cycle (All et al., 1987). These authors estimated that $>95 \%$ of the eggs and young larvae die from environmental factors, pathogens, parasites, or starvation. However, only a few borers can cause extensive damage or vine death. Factors that affect GRB survived and that must be considered in devising integrated control strategies include genetic differences in grape root susceptibility to GRB larvae; environmental conditions; and biological, cultural, and chemical control factors.

\section{Genetic differences among grape rootstock and cultivars}

GRB larvae attack bunch (subgenusEuvitis) and muscadine (subgenus Muscadinia) grapes. Wylie (1972) compared GRB tolerance among bunch-grape rootstock in a field study in Arkansas and found that vigor differences among rootstock lines did not correlate with amount of GRB damage observed. Wylie identified 10 promising rootstocks, including 'Richter', 'Munson', and 'Harmony'. Adlerz and Hopkins (198 1) reported apparent differences in GRB damage among bunch and muscadine rootstock and cultivars in Florida. Bunchgrape rootstock 'Tampa', 'Dog Ridge', and 'Lake Emerald' were heavily infested by GRB Among muscadines, 'Higgins', 'Hunt', and 'Jumbo' were heavily infested. In contrast to the early muscadine literature (Brooks, 1907), Webb and Mortensen (1990) reported that muscadine cultivars had more GRB damage, measured as tunnels per root, than the bunchgrape rootstock evaluated in their 10-year field study in Florida. Among muscadine cultivars, they found that 'Southland' and 'Regale' were less damaged than 'Welder' and 'Hunt'. In a pot study with controlled GRB inoculation, Webb and Mortensen (1990) reported that four of 14 hybrid bunch-grape rootstock had less GRB damage than Tampa. AU four rootstocks had $V$. shuttleworthii House in their background. This species should be investigated further as a potential source of GRB resistance for bunch-grape rootstock.

\section{Environmental factors}

Soil temperature and water status have been associated with survival rate of eggs and young larvae and with timing and duration of adult emergence. Extremely high or low soil water content increases egg and young larvae mortality. Dry soil combined with high soil temperature caused high mortality of eggs and young larvae (Sarai, 1972; Townsend, 1990). Townsend (1990) reported maximum vineyard soil temperatures $>50$ to $60 \mathrm{C}$ at a $1.0-\mathrm{cm}$ depth in a dry year. Time of seasonal pupation and adult emergence also is delayed by high temperature (Webb et al., 1992). The adult emergence period ceased shortly before autumnal decreases in daily temperature (Webb et al., 1992).

Heavy rains following egg hatch lower soil $\mathrm{O}_{2}$ concentration and drown eggs and young larvae (Webb et al., 1992). Time of peak adult emergence is delayed and the duration of emergence is prolonged in wet years (Clark and Enns, 1964; Sarai, 1972). Trickle irrigation, especially in conjunction with application of composted bark mulch in the vineyard, increased GRB activity and vine loss in Missour' (Townsend, 1990).

Timed manipulation of soil depth around vines has been used successfully to interfere with pupation and adult moth emergence (All et al., 1985; Sarai, 1969; Wylie, 1972) and is discussed under cultural control factors.

\section{Biological control}

Naturally occurring pathogens and predators of GRB eggs, larvae, and pupa include white muscardine fungus [Beauveria bassiana (Balsamo) Buillemin], green muscardine fungus [Metarrhizium anisopliae (Metchnikoff) Sorokin], Aspergillus flavus Link ex Fr., a neoaplectanid nematode [Neoaplectana carpocapsae Wieser (all strains)], a braconid wasp parasite (Bracon caulicola Gaham), and predatory larvae of a firefly (Photuris pennsylvanica De Geer) and soldier beetle (Chauliognathus pennsylvanicus De Geer) (Brooks, 1907; Clarke and Enns, 1964; Dutcher and All, 1978c; Sarai, 1972; Wylie and Johnson, 1978). Adult GRB moths also are subject to predation by birds such as barn swallow (Hirundo rustica erythrogaster Boddaert), mocking bird (Mimus polyglottus L.), and great crested flycatcher (Myiarchus crinitus L.) (Brooks, 1907; Clarke and Enns, 1964). Dutcher and All (1978c) studied two sites in Georgia and determined that GRB mortality from natural causes was greatest a the egg and first-instar larval stages $(\approx 70 \%$ and $98 \%$ mortality, respectively). Mortality of subsequent larval instars in root feeding sites, pupae, and adults was much lower, $\approx 4 \%, 5 \%$ to $7 \%$, and $2 \%$ to $16 \%$, respectively. Biological control of GRB has failed (All et al., 1981; Dutcher and All, 1976; Pellet, 1975).

\section{Cultural management}

Weeds under the vine protect eggs and newly hatched larvae from desiccation and hide eggs and larvae from predators (All et al.. 1987). Weed cover also protects eggs from contact with insecticidal sprays. Maintaining a weed-free environment in the vineyard row, whether by herbicide use or mechanical means, increases mortality of GRB larvae and emerging adults. Survival is further reduced if the soil under the vine is packed and dry (Sarai, 1972; Townsend, 1990).

Using a mechanical grape hoe to mound soil ( 20 to $25 \mathrm{~cm}$ deep, $\approx 60 \mathrm{~cm}$ wide) along the grape row increased soil depth and controlled emerging pupae $100 \%$ (Sarai, 1969). Mounding must be done only after most of the larvae have spun cocoons, otherwise larvae will continue to migrate to the soil surface. Also, the mounds must be removed in late fall, before the vines produce lateral roots in the mounded soil (All et al., 1987; Pellet, 1975). This procedure currently is recommended in bunch grapes (All et al., 1987). However, muscadine grapes have shallow root systems compared to bunch grapes (Olien, 1990), and cultivation may damage muscadine roots

Placing a plastic barrier on the soil surface has shown promise in experiments (Attwood and Wylie, 1963). A continuous $120-\mathrm{cm}$-wide band of plastic placed down the entire vineyard row resulted in nearly $100 \%$ control of adults emerging from the soil and also prevented first-instar larvae from reaching grape roots. However, this approach appeared impractical because the plastic tore and degraded under sunlight. In a similar study, an asphalt material was sprayed over a $45-\mathrm{cm}$ radius around the vine trunk (1.8 liters of material per plant)just before adult borer emergence (Wylie, 1966). This mulch layer remained intact for 6 weeks before deteriorating. Some pupae died under this material. However, pupal cases were found protruding through the mulch layer, which indicated that this material was not effective in preventing adult emergence.

Good vineyard management and site selection that result in strong, healthy vines, with minimal environmental and biological stresses, also are important factors that increase the effectiveness of GRB control and increase vine tolerance to roots lost to feeding GRB larvae (All et al., 1987). Such procedures include preventing nutrient, drought, and waterlogging stresses; controlling other destructive grape pests and pathogens; and preventing soil erosion and competition from weeds. Wylie (1968) noted that even with heavy GRB infestation, Missouri vineyards that received good cultural care remained productive and were apparently able to overcome root damage caused by GRB. Severe GRB infestations are often associated with poorly drained sites, a condition that encourages root growth near the surface and decreases vine vigor (All et al., 1987). If GRB infestations can be kept under control and away from the crown region near the trunk, a healthy, vigorous vine may produce new roots faster than GRB larvae can destroy them.

\section{Chemical control}

Insecticidal sprays applied to control foliar 
feeding insects [i.e., Japanese beetle (Popillia japonica Newman) and grape berry moth (Endopiza viteana Clemens)] tend to increase GRB larvae survival by decreasing populations of natural predators. Dutcher and All (1978c) observed that egg mortality by predation was $62 \%$ without applying foliar insecticides and $12 \%$ with them. However, these same insecticidal sprays directly increased egg mortality to $75 \%$ compared to $23 \%$ without them. Thus, the total number of surviving GRB eggs and larvae was about the same with and without foliar insecticides.

Once in the root, GRB larvae are well insulated from predators and environmental stresses, as well as from soil-applied insecticides. Several insecticides and soil fumigants have been evaluated for subterranean control of GRB (Adlerz, 1984; All and Dutcher, 1977; Dutcher and All, 1978c). These authors reported that injecting soil with the fumigants ethylene dibromide (EDB) and ethylene dichloride (EDC) successfully controlled subterranean larvae in established vineyards. However, these materials are no longer registered for use.

Applying the organophosphorous insecticide [0,0 -diethyl 0 -(3,5,6 -trichloro-2pyridinyl)phosphorothioate] (chlorpyrifos, Lorsban 4E; Dow Chemical Co,, Midland, Mich.) to the soil surface also successfully controlled GRB. Current recommendations suggest that chlorpyrifos be applied as a chemical barrier on the soil surface, timed to control eggs and first-instar larvae before they penetrate the soil (All et al., 1987). The compound is not highly toxic to pupae and does not inhibit adult emergence (All et al., 1985). Chlorpyrifos provides $\approx 4$ weeks of protection when applied at recommended rates to $1.4 \mathrm{~m}^{2}$ of soil surface around the vine trunk in July (All et al., 1985, 1987). Complete coverage with insecticide requires a weed-free soil surface. Restrictions on chlorpyrifos use require that it be used only once per year and not later than 35 days before harvest. This requirement poses a particular problem for southern grape growers, since adult emergence and egg hatch occurs well into the month before harvest (Snow et al., 1991), and as late as October in Miami (Webb et al., 1992).

Saturating vineyards with GRB sex pheromone to disrupt mating has shown promise in vineyard trials. Successful GRB mating disruption was first reported using Z,Z-3, 13octadecadien- 1-01 acetate [(Z, Z)-3, 13-ODDA], a common pheromone component of other sesiid moths, such as peach tree bore (Synanthedon exitiosa Say) (Johnson et al., 1981, 1986). The active component of the GRB pheromone differs somewhat from other sesiid moths and was identified as (E, Z)-2, 13 ODDA (Schwarz et al., 1983). A mixture of (E,Z)-2,13-ODDA with $1 \%$ (Z,Z)-3,13-ODDA was highly efficient in attracting GRB males for trapping purposes and in disrupting mating (Aim et al., 1989; Snow et al., 1987). Johnson et al. (1991) reported that 254 dispensers of either pheromone (not mixed) per hectare can provide effective and environmentally safe control of GRB in vineyards with a low to moderate GRB population.

\section{SUMMARY}

The difficulty in detecting GRB infestation in vineyards, the cumulative and severe nature of the injury; and the lack of a satisfactory insecticidal or other control strategy make an integrated approach essential for preventing and controlling GRB. The number of factors reported in the literature that improve GRB control and vine tolerance is encouraging. Further work on integrated control of GRB is needed to improve efficacy of control through environmentally sound practices. In addition to GRB control, such practices would also directly benefit vineyard longevity, vigor, productivity, and tolerance to other physical and biological stresses.

\section{Literature Cited}

Adlerz, W.C. 1984. Grape root borer: Review and status in Florida. Leesburg Agr. Res. \& Educ. Ctr. Res. Rpt. LBG 84-4.

Adlerz, W.C. and D.L. Hopkins. 1981. Grape insects and diseases in Florida. Proc. Fla. State Hort.Soc. 94:331-336.

All, J.N. and J.D. Dutcher. 1977. Subsurface and surface insecticide applications to control subterraneanlarvaeof the grape root borer. J. Econ. Entomol. 70:649-652.

All, J. N., J.D. Dutcher, and M.C. Saunders. 1987. Control program for the grape root borer in grape vineyards of the eastern United States. Down to Earth 43:10-12.

All, J. N., J.D. Dutcher, M.C. Saunders, and U.E. Brady. 1985. Prevention strategies for grape root borer (Lepidoptera: Sesiidae). J. Econ. Entomol. 78:666-670.

All, J. N., M.C. Saunders, J.D. Dutcher, and A.M. Javid. 1981. Susceptibility of grape root borer larvae, Vitacea polistiformis (Lepidoptera: Sesiidae) to Neoaplectana carpocapsae (Nematoda: Rhabditida): Potential of host kairomones for enhancement of nematode activity in grape vineyards. Misc. Publ. Entomol. Soc. Ark. 12:9-14.

Aim,S.R., R.N. Williams, D.M. Pavuk, J.W. Snow, and M.A. Heinlein. 1989. Distribution and seasonal flight activity of male grape root borers (Lepidoptera: Sesiidae) in Ohio. J. Econ. Entomol.82(6): 1604-1608.

Attwood, V.G. and W.D. Wylie. 1963. Grape root borerthreatens vineyards. Ark. Farm Res. 12:6.

Brooks, F.E. 1907. The grapevine root-borer. West Virginia Agr. Expt. Sta. Bul. 110:19-30.

Clark, G.N. and W.R. Enns. 1964. Life history studies of the grape root borer (Lepidoptera Aegeriidae) in Missouri. J. Kan. Entomol. Soc. 37:56-63.

Dutcher, J.D. and J.N. All. 1976. Beware the grape root borer: J. Amer. Fruit Grower 96: 18-19.

Dutcher, J.D. and J.N. All. 1978a. Reproductive behaviorof Vitacea polistiformis Harris. J. Ga. Entomol.Soc.13:59-63.

Dutcher, J.D. and J.N. All. 1978b. Models of the distribution of subterranean stages of Vitacea polistiformis in Concord grape vineyards. Environ. Entomol. p. 461-465.

Dutcher, J.D. and J.N. All. 1978c. Survivorship of the grape root borer in commercial grape vineyardswithcontrastingculturalpractices.J.Econ. Entomol. 71:751-754.

Dutcher, J.D. and J.N. All. 1978d. Predictive mod- els for the summer activity of Vitacea polistiformis in Concord grape vineyards. Environ. Entomol. 7:456-460.

Dutcher, J.D. and J.N. All. 1979. Damage impact of larval feeding by the grape root borer in a commercial Concord grape vineyard. J. Econ. Entomol.72:159-161

Johnson, D. T., B.A. Lewis, and J.W. Snow. 1991 Control of grape root borer (Lepidoptera: Sesiidae) by mating disruption with two synthetic sex pheromone compounds. Environ. Entomol. 20(3):930-934.

Johnson, D. T., R.L. Mayes, and P.A. Gray. 1981 Statusofgraperootborer(Lepidoptera:Sesiidae) management and feasibility of control by disruption of mating communication. Misc. Publ. Entomol. Soc. Ark. 12:1-7.

Johnson, D.T., J.R. Meyer, and R.L. Mayes. 1986. Evacuationofhereonlaminateddispensersbaited withZ,Z-3,13-octadecadien-101acetateforsuppression of the grape root borer, Vitacea polistformis (Harris), (Lepidoptera: Sesiidae), populations in grapes. J. Entomol. Sci. 21:23 1236.

McGiffen, K.C. andH.H. Neunzig. 1985. Aguide to theidentificationandbiology of insects feeding onmuscadine and bunch grapes in North Carolina. North Carolina Agr. Res. Serv. Bul. 470.

Olien, W.C. 1990. The muscadine grape: Botany, viticulture, history, and current industry. HortScience 25:732-739.

Pellet, D.K. 1975. The grape root borer in South Carolina. Clemson Univ. Ext. Serv. Circ. 550.

Sarai,D.S.1969. Effect of burial of grape root borer pupae on adult emergence. J. Econ. Entomol. 62:1507-1508.

Sarai,D.S. 1972. Seasonal history and effect of soil moistureonmortalityofnewlyhatched larvae of the grape root borer in southern Missouri. J. Econ.Entomol.65: 182-184.

Schwarz, M., J.A. Klun, B.A. Leonhardt, and D.T. Johnson. 1983. (E,Z)-2, 13-octadecadien- 1-ol acetate: A new pheromone structure for sesiid moths. Tetrahedron Lett. 24 1007-1010.

Snow, W.J., D.T. Johnson, and J.R. Meyer. 1991. Theseasonaloccurrenceof the grape root borer, (Lepidoptera: Sesiidae) in the Eastern United States. J. Entomol. Sci. 26(1): 157-168.

Snow, W.J., M. Schwarz, and J.A. Klun. 1987. The attraction of the grape root borer, Vitacea polistiformis (Harris) (Lepidoptera: Sesiidae) to (E,Z)-2, 13-octadecadienyl acetate and the effectsofrelatedisomersonattraction.J.Entomol. Soc. 22:371-374.

Townsend, H.G. 1990. Grape insect pest monitoring and IPM in the Missouri Ozarks, p. 11 7-129. In: N.J. Bostanian, L.T. Wilson, and T.J. Dennehy (eds.). Monitoring and integrated management of arthropod pests of small fruit crops. Intercept, Andover, England.

Webb,S.E.andJ.A. Mortensen. 1990. Evaluationof bunch grape rootstock and muscadine varieties forresistancetograperootborer.Proc. Fla. State Hort.Soc. 103:310-313

Webb, S.E., R.K. Sprenkel, and J.L. Sharp. 1992 Seasonalflightactivityofgraperootborer(Lepidoptera:Sesiidae)in Florida. J. Econ. Entomol. 85(6):2161-2169.

Wylie,W.D. 1966. Grape root borer research. Proc. Ark. State Hort. Soc. 87:21-22.

Wylie,W.D.1968. The grape insect situation. Proc Ark. State Hort. Soc. 89:93-94.

Wylie, W.D. 1972. Grape root borer research. Pmt Ark. State Hort. Soc. 93:94-95.

Wylie, W.D. and D.T. Johnson. 1978. Summary of grape root borer and scale research. Proc. Ark. StateHort. Sot. 99:108-1 10. 